\title{
The use of Jigsaw strategy to improve students' reading comprehension achievement
}

\author{
Tuti Alawiyah $^{1}$, Ujang Suparman ${ }^{2}$, Khairun Nisa ${ }^{3}$ \\ English Education Study Program, University of Lampung ${ }^{1,2,3}$ \\ ${ }^{1}$ Correspondence: Tutialawiyah776@ yahoo.com
}

\begin{abstract}
The objectives of this research are to find out the improvement of the students' reading ability before and after the implementation of jigsaw strategy and also to identify student perception about the use of jigsaw strategy at SMK N 1 Candipuro. This research was a quantitative research and the method was one group pretest and post-test design. The reading test was administrated as the instrument in this research. In pretest, students mean score was 53. 86 while in post-test it increases to 65.46; the gain obtained in pre-test to post-test is 11.59 . The analysis of SPSS 20 shows that there is improvement of students' reading ability after the implementation of jigsaw strategy; Based on seeing the analysis of students' work in pre-test and post-test on each aspect of reading. It could be found that determining main idea was the aspect that increased the most.
\end{abstract}

Keyword: Jigsaw strategy, Reading

\section{INTRODUCTION}

English has four language skills; those are listening, speaking, reading, and writing. They are supported by some components; they are vocabulary, grammar, and pronunciation. In learning English, one of main skills that the student needs to acquire is reading. The purpose of teaching reading is to make the students able to read the text effectively. Therefore, students can get the information from the text they read and learn not only to understand the structure of the texts but also to comprehend the content of the texts. According to Harmer(2001) the reading skills should be acquired by students. They need to be able to scan a text and skim a text to get general idea of the text that they read. Both teachers will expect them to be more utilitarian with literary work when reading comprehension.

Based on the curriculum, the purpose of teaching reading in that level is the students have to be able to understand, to respond, and to comprehend thetexts. During the observation at SMKN 1 Candipuro, the strategies that the teacher use are teacher asked students to read the texts, translate the texts, answer the question of the texts and collect students' task. From the description above, the strategy that teacher used didn't give a good learning process to the students. The other problem is that during the teachinglearning process in the classroom, the students did not enjoy the reading activities because the activity is monotonous. As a result, the students' achievement in reading comprehension was not satisfied. They also said that they were not motivated enough to deal with reading text material.

Jigsaw is a kind of cooperative learning task that requires learners to communicate with each other in order to fill in missing information and to integrate it with other information. Şahin(2010) argues that "Jigsaw technique allows students to actively participate in learning process.By being constantly 
subjected to this method, students should feel more comfortable about their roles" (p.778). Wittrock(1991) concludes that it is important to change students' perception of their roles in learning from one of recording and memorizing information to one of generating understanding by relating concepts to their experiences and to their knowledge base. What Wittrock stresses on is the idea that interactive approach recognizes the importance of both the text and reader's learning characteristics in the reading process. A reading passage is divided into four or five parts. Make sure each part of the text can be read and understood independently. The class is divided into groups of four or five pupils, called expert groups. Each expert group is given one part of the text to learn. The purpose of these groups is to enable learners to help each other study the material. The pupils will then be divided into study teams or home groups. Each study team has representatives from each of the expert groups. Each member of the group now teaches and shares his/her part of the text with the rest of the study team. The time given to the "sharing" phase depends on the difficulty and length of the material.

According to the explanation above, the researcher will apply Jigsaw strategy to improve students' comprehension in reading. It is expected that by using Jigsaw, the students can take the information from the text well. The researcher also had a thought in assuming the theories that Jigsaw will give opportunity for the students to understand deeper about the text easily. Besides to produce students' comprehension, by applying this strategy is expected to make the students more active and they easily share idea with other students. Students are believed to gain more motivation. It is hoped that this strategy can overcome the students' problem in reading.

Based on these problems and reasons, the researcher would like to find out about what aspect that improved the most after being taught by jigsaw strategy in reading comprehension.

\section{METHODOLOGY}

This study is intended to find out whether teaching using Jigsaw strategy can increase students' reading comprehension in recount text or not and to find which aspect that improved the most. In conducting the research, the researcher will use true experimental design by giving different topics for each treatment in every test. According to Hatch \& Farhady(1982) the formulated is:

\section{T1 X T2}

The description presented as follows:

$$
\begin{array}{ll}
\text { T1 } & : \text { Pre-test } \\
\mathrm{X} & : \text { Treatment (Jigsaw strategy) } \\
\mathrm{T} 2 & : \text { Post-test }
\end{array}
$$

\section{Population and Sample}

The population of this research is the first year students of SMKN 01Candipuro in academic year 2021/2022. One class will be taken as the sample of this study and the class consisted of 30 students. The researcher will use one class randomly to determine the class. 


\section{Research Instrument}

Research instruments are tools or facilities used by researchers in collecting data so that their work is easier with the results are better, in a more accurate, complete, and systematic sense easier to process (Arikunto, 2011).In gathering the quantitative data of this research, the researcher will use a test which is a reading test that consists of test and non-test. To make them clearer here are the following details:

\section{Pre Test}

A pre-test will be conducted to find out the students initial reading comprehension before treatments. The test will be administered in 60 minutes with 30 items of multiple choices reading test. The pretest items will be arranged after conducting a try-out test.

\section{Post Test}

A post-test was conducted in the end of treatments in order to find out the significant improvement in students reading comprehension achievement. The test will be administered in 60 minutes with 30 items of multiple choices reading test.

\section{RESULTS AND DISCUSSIONS}

\section{The Result of The Pre-test}

The pre-test was administered in the experimental class before they were given the treatment. There were 25 items that have been tested. To investigate students' reading comprehension skill, the result of the pretest was calculated manually through Microsoft Excel and further be statistically analyzed by using SPSS 20.The result showed the summary statistic of students' pre-test score. The result showed that the total of the pre-test was 1616. The mean of the pre-test was 53.8; the median was 58.0; and the mode was 60.0.

\section{The Result of The Post-test}

The post-test was administered to investigate whether or not there is a significant improvement after the implementation of Jigsaw strategy. There were 25 items of post-test that have been tested.

The result showed the summary statistic of students' post-test score. The result showed that the total of the post-test was 1964. Additionally, the mean of the post-test was 65.4, median was 68.0, and the mode was 72.0

Table 1 The Gain of Students' Pre-test and Post-test

\begin{tabular}{|cccc|}
\hline \multirow{2}{*}{ Mean } & Pre-test & Post-test & Gain \\
\cline { 2 - 4 } & 53.8 & 65.4 & 11.6 \\
\hline
\end{tabular}

As can be seen in Table, it is clear that the students' reading comprehension ability increased significantly. It can be seen from the result of the pre-test mean (53.8) and compared to the post-test mean (65.4) which obtain the gain 11.6.

\section{Normality Test}

The data should be tested the normality to determine whether the data were distributed normally or not. In other words, the researcher used One-Sample Kolmogorov-Smirnov Formula through SPSS. The data was 
said normal if the result was higher than 0.05 . The result of pre-test and post-test normality is presented as follows:

Table 2 Normality Test Result

One-Sample Kolmogorov-Smirnov Test

\begin{tabular}{|llrr|}
\hline & & Pretest & Posttest \\
\hline $\mathrm{N}$ & & 30 & 30 \\
Normal Parameters $^{\mathrm{a}, \mathrm{b}}$ & Mean & 53.867 & 65.467 \\
& Std. Deviation & 11.4943 & 11.9992 \\
& Absolute & .203 & .152 \\
Most Extreme & Positive & .086 & .152 \\
Differences & Negative & -.203 & -.140 \\
& & 1.113 & .830 \\
Kolmogorov-Smirnov Z & & .168 & .496 \\
Asymp. Sig. (2-tailed) & & & \\
\hline
\end{tabular}

a. Test distribution is Normal.

b. Calculated from data.

From the Table above, it can be seen that the sig 2-tailed result of the pre-test was 0.168 and the post-test was 0.496 . Both of the result reached the higher value than 0.05 which can be said both of the pre-test and post-test were distributed normally.

\section{Hypothesis Testing}

Hypothesis testing was used to decide which hypothesis should be accepted or rejected. The researcher used Paired Sample T-Test in which the significance level was determined if the result is lower than 0.05 . The data of hypothesis testing is presented as follows:

Table 4.7 Table of Result of Hypothesis Testing

\begin{tabular}{|c|c|c|c|c|c|c|c|c|}
\hline \multicolumn{9}{|c|}{ Paired Samples Test } \\
\hline & \multicolumn{5}{|c|}{ Paired Differences } & \multirow{4}{*}{$\frac{t}{10070}$} & \multirow[b]{3}{*}{ df } & \multirow[b]{3}{*}{ Sig. (2-tailed) } \\
\hline & \multirow[b]{2}{*}{ Mean } & \multirow[b]{2}{*}{ Std. Deviation } & \multirow{2}{*}{$\begin{array}{l}\text { Std. Error } \\
\text { Mean }\end{array}$} & \multicolumn{2}{|c|}{$\begin{array}{c}95 \% \text { Confidence Interval of the } \\
\text { Difference }\end{array}$} & & & \\
\hline & & & & Lower & Upper & & & \\
\hline $\begin{array}{ll}\text { Pair } 1 \text { Posttest - Pretest }\end{array}$ & 11.6000 & 5.7870 & 1.0566 & 9.4391 & 13.7609 & & 29 & .000 \\
\hline
\end{tabular}

As seen in Table 4.7, the result of hypothesis testing is shown. The result showed that the sig 2-tailed value was 0.000 which was lower than 0.05 . Moreover, to ensure the sig 2-tailed result, the t-value (10.979) could be compared to the t-table of 30 (N-1) students which was significant to 2.045 (10.979 > 2.045). In conclusion, based on the result of sig 2-tailed and t-value of Paired Sample T-Test, it could be said that Jigsaw strategy give significant difference of students' reading comprehension. 


\section{CONCLUSIONS AND SUGGESTIONS}

In line to the findings that the researcher has found in the previous chapter, the conclusions draw in the following:

Jigsaw strategy gives a significant difference in students' reading comprehension ability. It can be seen from the result of the pre-test and post-test mean which have been compared with the result of the differences 11.6. Furthermore, the result of hypothesis testing proved that there is an increase of where the level of significance is lower than the alpha $(0.000<0.05)$. It can be said that students' reading comprehension ability differences after the implementation of Jigsaw.

Refer to the previous conclusion, the researcher proposed suggestions as follows:First,suggestions for teacher. English teachers who mostly use conventional teaching strategy are suggested to use Jigsaw strategy because it can influence students' reading comprehension ability. It involves the activity of students to work in group and build communicative skill. Last, The teacher can apply Jigsaw strategy in teaching other English skill, such as writing, speaking, and listening.

Second, suggestions for further research. Further researcher may conduct a study using Jigsaw strategy in more than three meetings in order to get more accurate result of data. The longer treatments are given, the more effective the result is collected. Next, Further researcher is suggested to find out students' attitude, or response to collect the data from the students' point of view. It can be collected by other instruments such as interview. Last, Further researcher is suggested to find out students' attitude, or response to collect the data from the students' point of view. It can be collected by other instruments such as interview.

\section{REFERENCES}

Arikunto, S. (2011). Prosedur penelitian: suatu pendekatan praktik. Rineka Cipta.

Harmer, J. (2001). How to teach English. Great Britain.

Hatch, E., \& Farhady, H. (1982). Research design and statistic for applied linguistics. New Burry House, Inc.

Şahin, A. (2010). Effects of jigsaw II technique on academic achievement and attitudes to written expression course. Educational research and reviews, 5(12), 777-787.

Wittrock. (1991). Educational psychology, literacy, and reading comprehension. Journal of Educational Psychologist, 26(2), 109-116. 